\title{
6f University
}

Paisey, C., and Paisey, N. J. (2016) Talent management in academia: the effect of discipline and context on recruitment. Studies in Higher

Education, (doi:10.1080/03075079.2016.1239251)

This is the author's final accepted version.

There may be differences between this version and the published version. You are advised to consult the publisher's version if you wish to cite from it.

http://eprints.gla.ac.uk/128785/

Deposited on: 20 September 2016

Enlighten - Research publications by members of the University of Glasgow http://eprints.gla.ac.uk33640 
Talent Management in Academia -

The Effect of Discipline and Context on Recruitment

\author{
Catriona Paisey*, University of Glasgow \\ Nicholas J Paisey**, Heriot-Watt University \\ *Accounting and Finance \\ Subject Group \\ Adam Smith Business School \\ University of Glasgow \\ Main Building \\ Glasgow \\ G12 8QQ, UK \\ Telephone: 01413302205 \\ Email: \\ catriona.paisey@glasgow.ac.uk \\ **School of Management and \\ Languages \\ Riccarton \\ Edinburgh \\ EH14 4AS \\ Telephone: 01314513550 \\ Email: \\ n.paisey@hw.ac.uk
}

\begin{abstract}
$\underline{\text { Acknowledgement }}$
This work was supported by the Irish Accountants' Educational Trust (no grant number exists). The authors confirm that this sponsor had no involvement in the study design; in the collection, analysis and interpretation of data; in the writing of the paper; or in the decision to submit it for publication.
\end{abstract}




\begin{abstract}
$\underline{\text { Abstract }}$
Although talent management is widely discussed in large for - profit organisations and multinationals, it has been little discussed in relation to higher education. This paper examines one aspect of talent management, recruitment, in academia in accounting, in two different countries, Scotland and the Republic of Ireland. It frames the study around three dilemmas - transparency versus autonomy, the power of human resources versus the power of academics, and equality versus homogeneity. It considers the recruitment context and drivers, what this tells us about how talent is defined, and the insights that can be gained from comparing recruitment across different disciplines and geographical contexts. By examining recruitment in one discipline across different contexts we show that recruitment is influenced by a complex interplay between subfield and context which can be linked to the strategic priorities of universities in the three contexts, resulting in different definitions of talent.
\end{abstract}

\title{
$\underline{\text { Keywords }}$
}

Recruitment, talent management, accounting, staffing, qualifications 


\section{$\underline{\text { Introduction }}$}

Since McKinsey consultants coined the term The War for Talent in the late 1990s, talent management has been recognised as a critical success factor for organisations but concern has been raised that the term lacks an adequate and generally agreed definition (Scullion and Collings, 2011). Talent management spans the employee lifecycle, from attracting and selecting employees to developing and retaining them (Scullion, Collings and Caligiuri, 2010; Stahl et al., 2012). This paper focuses on the recruitment stage of this lifecycle.

Current literature on talent management has mainly been conceptual (Thunnissen, Boselie and Fruytier, 2013a), has paid little attention to implementation and power processes (Watson, 2004) or context (McKenna, Richardson and Manroop, 2010; Van den Brink, Thunnissen and Fruytier, 2013) and has focused mainly on for-profit, corporate settings (Scullion and Collings, 2011; Thunnissen et al., 2013a). One exception is Van den Brink et al.'s (2013) examination of talent management in academia in which they describe the ability to attract top talent as a crucial issue for universities. The effects of making poor recruitment decisions include increased costs and employee turnover, and lowering of morale in the existing workforce (ACAS, 2014). Van den Brink et al. (2013) examined recruitment and selection practices in three disciplinary areas in academia in the Netherlands - humanities, STEM (science, technology, engineering and mathematics) and medical sciences - and found that academic fields differ in how appointments are organised, how candidates are sought and identified, and how performance indicators play a role in recruitment. They identify three key dilemmas relating to human resource management for universities, expressed in the following dimensions: transparency versus autonomy, the power of human resources versus the power of academics, and equality versus homogeneity, with each disciplinary area sitting 
at different points on these dimensions but with a tendency towards autonomy, power resting with academics and homogeneity. This paper aims to extend the work of Van den Brink et al. (2013) and responds to Thunnissen, Boselie and Fruytier's (2013a) call for further research to examine talent management in practice in public and non-profit organisations.

Like Van den Brink et al. $(2013,181)$, we consider recruitment and selection as 'embedded in a global, economic, political and socio-cultural context'. We extend Van den Brink et al.'s (2013) work by focusing on the recruitment stage in academia in accounting, a subfield not included in Van den Brink et al.'s study, and across different geographical contexts, Scotland and the Republic of Ireland. Scotland and the Republic of Ireland were chosen since these countries are subject to different funding and regulatory models. In particular, Scotland participates in regular research assessment processes - the previous Research Assessment Exercises (RAEs) and their replacement, the Research Excellence Framework (REF) whereas the Republic of Ireland does not. These processes have been said to have affected the working life of academics, especially in relation to increased expectations around research performance and the development of university performance measurement processes (Parker, 2011b). Within the accounting field, there has also been some suggestion that they have affected recruitment into academia (Duff and Monk, 2006). An examination of recruitment into accounting in academia in Scotland and the Republic of Ireland therefore allows for comparisons to be drawn across different funding contexts and to enable a better understanding of the interplay between disciplinary subfield and country context. We further separate accounting in Scotland into old universities (those existing before 1992) and new universities (those formed out of prior institutions that were able to gain university status following the passing of the Further and Higher Education Act 1992). These institutions differ in research depth and ethos. Hence, treating these two groups of Scottish universities 
as two separate contexts allows for an examination of differences both between and within countries. Our selected contexts are described in more detail later in the paper.

In order to frame the paper, we examine recruitment in terms of the dimensions of transparency versus autonomy, the power of human resources versus the power of academics and equality versus homogeneity. In addition, we examine the effect of discipline-specific factors identified from prior literature that are relevant to the recruitment process in order to better understand the specific decision-making context: the trend towards the recruitment of $\mathrm{PhD}$ holders rather than professionally qualified staff, the development of the business or management school, and the effect of research assessment on recruitment. This paper therefore aims to contribute to understanding of one stage of academic talent management (the recruitment stage) as implemented within one disciplinary subfield (accounting) and further explores the influence of context by comparing recruitment across two geographical settings (Scotland and the Republic of Ireland), further subdividing Scotland into two subcontexts (old and new universities) that have different historical, structural and funding environments. Our research questions are:

1. What does our examination of recruitment in our chosen contexts tell us about how talent is defined in these contexts?

2. How does recruitment in our chosen contexts sit in relation to the three dilemmas of transparency versus autonomy, the power of human resources versus the power of academics, and equality versus homogeneity?

3. To what extent have the trends identified in the literature review in relation to the increasing likelihood of the recruitment of $\mathrm{PhD}$ holders rather than professionally qualified staff, the development of the business or management school and the effect of research assessment on recruitment, affected our three chosen contexts? 
4. Drawing the above three research questions together, to conclude, what insights into the interplay between subfield and context can be gained from comparing recruitment in our chosen disciplinary subfield of accounting across two distinct geographical contexts and different types of universities?

This paper is structured as follows. First, prior literature is reviewed relating to talent management, the three dilemmas identified by Van den Brink et al. (2013), and contextual factors specific to the field of accounting. Then the context and research methods are explained before reporting and analysing the results. Finally, discussion and conclusions are presented. Overall we find that recruitment in our selected contexts differs from the findings presented by Van den Brink et al. (2013) in relation to the three dilemmas, and that these differences can be attributed to underlying contextual factors that reflect differences in academic disciplines and geographical areas.

\section{$\underline{\text { Literature Review }}$}

\section{Talent Management and Academic Talent}

Scullion et al. (2010, 106) define global talent management as including:

all organizational activities for the purpose of attracting, selecting, developing, and retaining the best employees in the most strategic roles (those roles necessary to achieve organizational strategic priorities) on a global scale.

Thus, global talent management must be linked to an organisation's global business strategy (Minbaeva and Collings, 2013). This has led to a redefinition of the role of the human resource function, with the work moving from being mainly focused on administrative support (for example in record-keeping and payroll) to a role that is more strategic, focusing on the alignment of talent management and leadership development with an organisation's strategic goals (Novicevic and Harvey, 2001; SHRM, 2006, 2008). Recently, human 
resources departments have moved away from working jointly with line management and instead take more responsibility for major policy decisions (CRANET/ SHRM/CIHRS, 2015). It is therefore important for researchers to consider an organisation's strategic priorities, ideally across more than one national context (Minbaeva and Collings, 2013).

Talent has been defined in a variety of ways, for example whether it is innate or alternatively, whether it can be acquired, with different organisations taking different approaches across the full spectrum (Meyers, van Woerkom and Dries, 2013). Other questions raised are whether talent must be manifest at the recruitment stage or whether instead its potential can be recognised, and whether the focus should be on people them selves or on their characteristics, such as their qualifications (Thunnissen et al., 2013b). Underlying conceptualisations variously view talent as capital, individual difference, giftedness, identity, strength or the perception of talent (Dries, 2013). In terms of implications for organisations, Minbaeva and Collings (2013) argue that it may not be necessary to always recruit the 'best' in terms of experience or qualifications, or 'A players' for example; instead it is important to focus on outputs and to consider how talent can best be deployed within an organisation.

Here, we focus on one aspect of talent management, the recruitment stage. Since little is known about how talent is defined in academic contexts (Van den Brink et al., 2013), this paper seeks to find out how academic heads of department of accounting conceptualise talent. Drawing on the above literature, we explore the alignment of talent with strategy, whether it focuses on a person's qualities or qualifications, and whether recruits need to possess such manifest talent at recruitment or whether they can be recruited for development potential. These issues are addressed in our first research question: What does our examination of recruitment in our chosen contexts tell us about how talent is defined in these contexts? 


\section{The role of Human Resources in Talent Management}

The role of human resource management in talent management has also been discussed in prior literature. Four roles played by human resources departments, relating to processes, culture, receptivity and leadership, have been identified and found in practice (Farndale, Scullion and Sparrow, 2010; Sparrow, Farndale and Scullion, 2013. In relation to the context of this paper, three dimensions have been identified as challenges or dilemmas for human resource managers in relation to academic recruitment (Van den Brink et al., 2013).

The first dimension is transparency versus autonomy. There is a greater emphasis on transparency and accountability in modern recruitment processes in an effort to be visible and open, thus reducing opportunities for corrupt or unethical practices. However, Van den Brink et al. (2013) found that there is still some way to go in academia since the relatively low level of increased transparency and accountability has not yet led to an equal recruitment process because closed or semi-closed recruitment practices continue to be employed in academia. For example, they found that young academics, frequently ones already situated internally in research student or junior academic roles, are often invited to apply for positions, while more senior staff are approached by departments or, increasingly, by recruitment agencies. They further found that academics strive to maintain their own professional expertise and influence over recruitment even where new human resources policies relating to recruitment have been introduced. These practices reflect a collegial rather than a managerial model (Deem, 1998).

The second dimension is the power of human resources versus the power of academics. Universities have large human resources departments but these primarily deal with the processing of applications, leaving academic recruitment decisions still largely in the hands 
of academic staff, with UK heads of department reporting that they had a significant degree of control over the recruitment process, despite the involvement of human resource departments and representation of other schools on selection boards (Metcalfe, Rolfe, Stevens and Weale, 2005). This is consistent with advice to human resources practitioners that it is generally better for line managers to lead the job analysis stage because of their specialist knowledge. If line managers play an integral part in selecting the most suitable member of staff, it is more likely that they will be committed to the new employee's success (Martin, Whiting and Jackson, 2010). Van den Brink et al. (2013) found that human resource managers are aware of the lack of transparency in recruitment practices, as discussed above, and the disconnect between policy and practice but find themselves unable to influence the process. Therefore, while recognising that human resource managers have a role to play in ensuring transparency and fair procedures, Van den Brink et al. (2013) argue that they often lack the power and inside knowledge to detect unfair practices. Hence, the relationship between administrators and academics can involve tension and conflict (Bourdieu, 1988).

The third dimension is equality versus homogeneity. There is some evidence that academics show a tendency to appoint in their own image, rather than encouraging increased diversity (Essed, 2004). Van den Brink et al. $(2013,192)$ found that elite academics involved in recruitment were influential in deciding which candidates were deemed to be excellent, with a tendency towards recruiting individuals 'congruent with their own personal and scientific preferences', and that it was difficult for others to challenge this elite academic conception of excellence. Bias in relation to gender, ethnicity and age have been cited as common examples of inequality in selection, leading to the risk that candidates may be unable to disrupt the status quo whereas, conversely, innovation and creativity are expected of them, with the result that 'more of the same' is unlikely to form a successful recruitment policy in the 
longer-term (Husu, 2000; Van den Brink et al., 2013). The second and third dimensions are therefore closely related to the first if, in acting autonomously, academics wittingly or otherwise act without transparency or equality.

Building on these three dimensions, our second research question is: How does recruitment in our chosen contexts sit in relation to the three dilemmas of transparency versus autonomy, the power of human resources versus the power of academics, and equality versus homogeneity?

\section{Recruitment in Accounting in Academia - Underlying Trends}

\section{Trends in Recruitment}

Accounting departments have long experienced difficulty in attracting and retaining suitable staff (Macve, 1989, Holland, 1991, Hopper, 2013). Uncompetitive academic salaries (compared with those of accountants) were considered to be a cause of recruitment difficulties, both in Scotland (Weetman, 1993) and particularly so in the south of England (Arnold and Sherer, 1988). Universities UK (2007) speculated that difficulties in accounting recruitment persist due to strong demand for such professionals in other parts of the economy, and uncompetitive university pay rates relative to other employment opportunities.

When accounting was first introduced as an academic discipline in universities in the early

$20^{\text {th }}$ Century, departments were largely staffed by professionally-qualified accountants (Zeff, 1997). However, from the 1980s the proportion of professionally-qualified staff in the UK began to decline markedly with the $\mathrm{PhD}$ rapidly becoming an increasingly prevalent entry qualification (Brown, Jones and Steele, 2007). The strong research focus in UK universities, encouraged by successive research assessment exercises, means that academic departments need staff to be able to publish quickly in order to be eligible for inclusion in research 
assessment (Duff and Monk, 2006). This may be easier for PhD entrants, who already have research experience, whereas most professionally qualified entrants do not. However, in the Republic of Ireland, where research assessment does not exist, recruitment continues to be predominantly from the ranks of professionally-qualified accountants.

\section{From Accounting Department to Business or Management School}

The profile of the accounting academic has therefore changed. Accounting departments have also changed. Accounting was often historically located in stand-alone departments but now it is frequently located within wider subject groupings that often sit as divisions or subject groups within broader business or management schools. The business school model dates back to the nineteenth century in the USA and Europe (Clarke, 2008) but it is only in more recent years that it has become widespread in the UK (Rowlinson and Hassard, 2011). Now, approximately $15 \%$ of the UK higher education population studies business and management subjects (Williams, 2010), justifying a separate home in the form of a business school.

The growth of the business school reflects a desire to break down 'silos' associated with narrow disciplinary groupings towards a more eclectic, corporate-facing academia (Lorange, 2006) but has the effect of reducing the visibility of individual disciplines such as accounting (Ashton et al., 2009). Parker $(2002,606)$ noted the trend towards university restructuring centred around a smaller number of large-scale faculties or divisions 'in pursuit of a smaller number of accountable strategic business units (SBUs), and a small number of senior managers accountable to them'. This, alongside a focus on outcomes, income and profit maximisation, corporate strategy and key performance indicators, makes the unit easier to manage (Parker, 2011a). A more managerialist culture, in which performance targets and measures have been introduced to measure and evaluate the productivity of individual 
academics, has also been said to have reconstituted the academic as a commodity (Willmott, 1995; Lawrence and Sharma, 2002), resulting in a shift away from the previously more collegial university culture in which academics had the scope to play a greater role in influencing their academic grouping (Saravanamutha and Tinker, 2002; Christopher, 2012).

\section{The Influence of Research Assessment}

Although there were attempts to assess research in the UK prior to the first research assessment exercise (RAE) in 1986, the RAEs formalised the process. RAEs have been held in the UK in 1986, 1989, 1992, 1996, 2001 and 2008 with the results of the most recent version, now renamed as the Research Excellence Framework (REF), announced at the end of 2014. These processes were designed to peer-review the quality of research performed in the UK higher education sector, not only providing an overview of research quality in the UK, but also determining the allocation of research funds from government to individual institutions (Otley, 2002). Their impact has been much greater than that, however, with UK research assessment playing 'an increasingly influential role in defining the meaning of life' in UK universities (Humphrey, Moizer and Owen, 1995, 141). The emphasis on research has increased, with research time being allocated as an institutional reward for prior success and to induce particular behaviours (Willmott, 1995; Harley and Lee, 1997) and there is growing evidence that the perceived quality and journal rankings of an individual's research outputs influences recruitment and promotion decisions (Beattie and Goodacre, 2012; Brooks, Fenton and Walker, 2014).

Although research productivity and quality judged by peer review in UK universities has a long history, Harley and Lee (1997) argued that the context within which research has been produced has changed. A managerialist approach has replaced collegiate-based control and 
informal peer review with universities being run increasingly as businesses. Efficiency, performance appraisal and measurement are emphasised, evidenced via a focus on research outputs, especially journal papers (Macdonald and Kam, 2011). The use of journal ranking lists (Tourish, 2011; Willmott, 2011; Mingers and Willmott, 2013; Rowlinson, Harvey, Kelly, Morris and Todeva, 2015) to evaluate papers fuses managerialism with peer review, institutionalising control over academic labour processes (Butler and Spoelstra, 2014).

In order to contextualise our study in terms of the above literature, this paper's third research question asks: To what extent have the trends identified in the literature review in relation to the increasing likelihood of the recruitment of $\mathrm{PhD}$ holders rather than professionally qualified staff, the development of the business or management school and the effect of research assessment on recruitment, affected our three chosen contexts?

Drawing our first three research question together, in conclusion, in order to address our fourth research question, we discuss the insights into the interplay between subfield and context that can be gained from comparing recruitment in our chosen disciplinary subfield of accounting across two distinct geographical contexts.

\section{Context and Method}

This paper examines recruitment into academia in accounting in two geographical contexts, Scotland and the Republic of Ireland. In Scotland, twelve institutions offer degrees in accounting. In all cases, accounting sits within a business or management school. We distinguish between 'old' and 'new' Scottish universities as their history and ethos differ. There are eight 'old' universities, comprising four ancient universities ${ }^{\mathrm{i}}$ established between 
1413 and 1582 and another four universities that gained university status in the $1960 \mathrm{~s}^{\mathrm{ii}}$. The Further and Higher Education Act 1992 led to the designation of additional 'new' universities $^{\mathrm{iii}}$. In the Republic of Ireland, the Universities Act 1997 recognises seven universities $^{\text {iv }}$. Accounting is taught at six, sitting within a wider business school in five of these institutions and in a college of business and law in another. Scottish higher education receives funding from the Scottish Funding Council with the amount dependent upon the results of regular research assessment, as discussed earlier. Irish higher education is funded by the Irish government but there has been no research assessment ex ercise in order to inform funding allocations. Therefore, by including Scottish and Irish universities, it is possible to compare the effects of different research assessment funding contexts.

We conducted semi-structured interviews with the heads of departments of accounting ${ }^{\mathrm{v}}$ at fourteen universities - five 'old' (two ancient and three others) and four 'new' universities in Scotland, and five in the Republic of Ireland. These interviews were in-depth interactions, ranging from one hour to two-and-a-half hours ${ }^{\mathrm{vi}}$. Fourteen was considered to provide sufficient coverage as, by that point, no new insights were obtained and saturation (Guest, Bunce and Johnson (2006) had occurred. Prior research studies have tended to interview human resource management professionals (Sparrow et al., 2013) or individuals seeking positions (Tansley and Tietze, 2013). Our interest was in the environment within which recruitment was taking place which would not be known to many applicants. Therefore, we selected a group previou sly unrepresented in the literature, heads of department, as, looking downwards, they would be close to the academics in their departments and therefore aware of recruitment from the perspective of their departmental members as well as from their own perspective. Looking upwards, heads of department can be viewed as having a privileged interpretation of what goes on in an organisation (Hinings, Thibault, Slack and Kikulis, 
1996), occupying a position between the members of their departments and senior management and typically involved in short-listing and sitting on selection panels for academic staff within their department. Hence they would be aware of both their own university policy and also of the factors that influence recruitment within their subject area. Seven held a professional qualification and later gained a PhD. Three held a professional qualification only. Two held a PhD only and two possessed neither qualification. Therefore, in total, ten individuals held a professional qualification and nine held a $\mathrm{PhD}^{\mathrm{vii}}$.

The interviews were semi-structured, asking heads of department firstly to describe the aims, ethos and composition of their departments, including the balance between professionally qualified and $\mathrm{PhD}$ recruits and changes over time; their own background; the heads' perceptions of the characteristics of the ideal recruit, including their assessment of the advantages and disadvantages of professionally qualified vis à vis $\mathrm{PhD}$ recruits; the factors that influence and drive recruitment; the process and key players in the making of recruitment decisions and the criteria for shortlisting and appointment with a focus on the role of heads, the wider school and university; and the importance and influence of research in the recruitment process and any other observations not covered elsewhere in the interviews. Although we had the three dimensions in mind, the words 'transparency', 'autonomy', 'power', 'equality' and 'homogeneity' were not used so as not to lead respondents but questions were asked to attempt to elicit underlying aspects relating to these dimensions. The interviews were recorded and transcribed verbatim. All interviews are reported anonymously.

The interviews were analysed by theme. Thematic analysis was considered to be appropriate as it is a flexible method for identifying, analysing, and reporting patterns and themes within 
data (Braun and Clark, 2006). Thematic analysis generally follows four distinct stages (Braun and Clark, 2006; Clark and Braun, 2013). First, in order to become familiar with the data, the recorded interviews were transcribed, read and re-read by the researchers. Second, the data was coded. Clark and Braun (2013) define a theme as a coherent and meaningful pattern in the data relevant to the research question, with the appropriateness of a theme lying in its ability to capture some level of patterned response or meaning within the data in relation to a specific research question. Drawing on the research questions, the themes initially used were centred around the views of the head of department on the type of recruit they were looking for and aspects of the recruitment process ${ }^{\text {viii }}$. The third stage of the process was to thematise the coded data, pulling together the codes from the across the entire dataset. Fourth, the themes were refined under the thematic headings of definitions of talent, transparency versus autonomy, the power of human resources versus the power of academics, equality versus homogeneity, recruitment trends, and the influence of research assessment.

\section{Findings}

\section{Transparency versus Autonomy}

In contrast with the findings of Van den Brink et al. (2013), the recruitment processes adopted in the three contexts considered in this paper (Scottish old, Scottish new and Republic of Ireland universities) did not appear to be especially closed or semi-closed. Posts were advertised and heads referred to the need to produce a job specification setting out the requirements and qualifications of the recruit, which is consistent with transparency (Thunnissen et al., 2013b). Also consistent with transparency, most recruits in Scotland appeared to be unknown to the department at the time of selection. Only one head in 
Scotland (in an old university) mentioned recruiting someone known to the department, a former student who had gained a professional accountancy qualification after graduation:

As a matter of fact we have someone joining us in August who has a degree and a professional qualification but no $\mathrm{PhD}$... it's not typical, because we knew the student, a really unusual case (Scottish old university B)

A different pattern was evident in the Republic of Ireland. There, recruitment is often initially into a contract position. Four of the five heads of department used such a process, one going as far as to say:

All of our recruitment is on a contract basis. If they demonstrate in that time they are serious about getting a $\mathrm{PhD}$, obviously we wouldn't expect them to come in and start from zero base and wrap it up in three years usually before, we would have a pretty good idea and so far we haven't gone wrong, in that, at the end of the three years, if a permanent post becomes available and that person performs well during the selection process then they get the permanent post (Republic of Ireland university E)

Therefore, a contract can be seen as, in effect, a probationary period, and often these would be converted into a permanent position:

We would often appoint people under contract, one year contract - recently there are a few longer ones - and that was an extremely genuine probation period in the sense that we could see how a person operated in a relatively small unit for a full year and we would all work together closely enough to have a pretty good idea of how somebody is performing. We would often have the opportunity then of converting the person who's been on a contract in to that permanent position (Republic of Ireland university C)

We kind of use that teaching assistant role over a two year period as a way of assessing a lot of people in the department (Republic of Ireland university D)

While this could be viewed as a process lacking transparency and giving favourable consideration to a contract employee, thus not treating all candidates equally, this would be to ignore the fact that the appointment to a contract position in the first place did appear to be transparent and impartial. This therefore represents a hybrid position not utilised by the Scottish heads of department. A key feature across the three contexts was the use of a job specification stating whether a candidate should possess a $\mathrm{PhD}$ or a professional accountancy 
qualification, indicating that talent was being defined in terms of qualifications rather than people (Thunnissen et al., 2013b).

\section{Talent conflated with qualifications - from professional qualification to PhD}

Consistent with Brown et al., (2007), heads of department in the old Scottish universities commented that, historically, the professional qualification had been the typical requirement but that it was becoming increasingly difficult to recruit professionally qualified staff:

It is going to be a big problem in the future I think for academic departments to get people who have got practical experience of a professional qualification (Scottish old university B)

Although the $\mathrm{PhD}$ route had become the established entry point, and a $\mathrm{PhD}$ was often specified as an essential requirement in a recruitment person specification with a professional qualification being listed as desirable rather than essential, heads differed in their views of the relative merit of the two qualifications. The usefulness of a professional qualification from a teaching perspective was recognised, particularly because of the credibility that a professional qualification was deemed to confer. However, there was a widespread view that it is difficult to consider a professionally qualified candidate without any research experience for a lecturing position since:

Judging the potential for research is very difficult if you have someone with a professional accountant background (Scottish old university C)

The specification of a $\mathrm{PhD}$ was considered to be a means of conveying an important message:

The aim is to try and go $100 \%$ research active... it's at least making it clear that we need a research orientated member of staff (Scottish old university D)

A $\mathrm{PhD}$ was thus linked to the wider university strategy, in keeping with the talent management literature's message that talent management should reflect and support strategic aims (Scullion et al., 2010; Minbaeva and Collings, 2013) and was viewed as an indicator of 
publication potential (Duff and Monk, 2006), indicating that talent was being defined in terms of potential rather than being required from the start (Thunnissen et al., 2013b). Within the Scottish old universities, the risk of recruiting someone who might not publish was a frequently expressed concern, so the possession of a $\mathrm{PhD}$ provided some objective 'evidence' (Scottish old university A) to justify a decision. Heads of department frequently referred to the risk of appointing someone who did not publish. Even when a PhD was taken as an indicator of potential, heads felt that there remained a huge risk that someone would not publish 'and we've suffered from this particular risk' (Scottish old university C). Therefore, the influence of risk-based managerialism, specifically the risk of recruiting someone who would not produce publishable assessable research, was uppermost in the minds of interviewees from the old Scottish universities.

\section{Alignment of talent management with wider institutional strategy}

Within the new Scottish universities, a different attitude was evident. In these universities, possession of a professional qualification was often considered to be advantageous:

Rightly or wrongly I think probably because of our strong professional links, we would be quite unhappy maybe taking on people who have not had professional accountancy training, which I suspect is probably not the norm, but I mean I think part of the valueadded comes from the fact that I am using people who have done it in practice (Scottish new university I)

Paradoxically, however, the fact that the new Scottish universities have a large proportion of professionally qualified staff in post already means that they do not necessarily see a real need to recruit more of the same:

At the moment we have substantial number of professionally qualified accountants and we have a very low level of research activity in our accounting group (Scottish new university $\mathrm{H})$

This head therefore wanted recruitment to focus more on research. Another head, in a university that specifies a master's degree rather than a $\mathrm{PhD}$ as essential, commented: 
We are going down the academic route because the level of research activity in our school generally is not great and we want it to increase along with the university idea. We don't want to recruit teachers, we don't want to recruit researchers, we're somewhere in between the two (Scottish new university G)

While the heads of department in the Scottish new universities were therefore more open to recruiting a professionally-qualified recruit than their old university counterparts, wider university pressures were making it more difficult for such a person to secure appointment because they do not possess publications, could not be included in the research assessment process or because the ethos of the university was undergoing change, indicating the alignment of talent management with strategic objectives (Scullion et al., 2010; Minbaeva and Collings, 2013), as had also been evident in the old Scottish universities. Having a PhD was considered by some to enable the recruit to deliver particular types of teaching, particularly post-graduate provision. Consistent with Parker (2011a), a degree of homogenisation was evident, with policy being determined at a more centralised level and paying attention to wider school or university strategic needs rather than discipline-specific ones (Ashton et al., 2009):

Therefore, the profile of an accounting lecturer becomes more similar to the profile of any academic entering the school (Scottish new university F)

However, concern was expressed about the suitability of $\mathrm{PhD}$ recruits to deliver teaching:

This is probably borne out of my experience of having to manage new starts and borne out of, to some extent out of personal prejudice - that you have people coming in with $\mathrm{PhDs}$ and you just kind of think "What do they know?", you know? Specialism's in a narrow area and they can't necessarily teach the whole range of subjects and therefore you've got to consider whether you can actually put them in front of a class (Scottish new university $\mathrm{H})$

The views of heads of department in the Scottish new universities therefore suggest a somewhat ambivalent view of the relative merits of $\mathrm{PhD}$ and professionally qualified recruits and their likelihood of recruiting from a particular qualification background. As with the old 
Scottish universities, the new Scottish universities used job/person specifications, indicating that best practice relating to transparency was being applied and recruitment was open with candidates not being individually approached.

\section{Talent related to research context}

In contrast to the Scottish heads of department, the heads in universities in the Republic of Ireland expressed a clear preference for a professionally qualified recruit and this was reflected in their job specifications. The main advantage cited by Irish interviewees for this preference is their ability to teach across a range of subjects and at a high level:

The differences I find between accounting people and people in other disciplines is that we get in people who can generally teach, very good teachers (Republic of Ireland university B)

Generally people that come in can go into any of these classes and so it's that flexibility, credibility and I would also have to say, a very professional approach to the way they go about things (Republic of Ireland university E)

This represented a focus on qualifications but also suggested that these heads were more interested in the type of person they were recruiting (Thunnissen et al., 2013b) than had been evident in the two Scottish contexts. Another issue is the value placed by the accounting departments on their relationship with the professional community, which they described as close and cordial, and which they attributed to the large proportion of the academics who are professionally qualified and who therefore find it easy liaise with, and be accepted by, the professional firms. However, some heads commented that an associated problem may be a lack of understanding of the academic role as professionally-qualified recruits may think that the job only involves teaching.

The above preference for a professionally-qualified recruit may be because the Republic of Ireland's experience of $\mathrm{PhD}$ qualified recruits has not been entirely positive: 
Now we have recruited two staff who have PhDs who are not professionally qualified accountants, now that has actually turned out to be quite a problem. Firstly because we cannot get them to teach a whole load of courses, you know they haven't the competence and in, in both cases actually I think the lack of professional training is extremely obvious. They are academics, not professionals. And you know those who don't have the professional accounting don't do things in a professional way and don't really fit in to the ethos of the department, you know? (Republic of Ireland university A)

A number of people that we have interviewed with $\mathrm{PhDs}$... their interviews would suggest to us that they would be the wrong type of person for the job, we just could not see them fulfilling the basic teaching requirement that we regard as significant, and because we're not under an obligation to achieve a particular research output at any cost, we can say "We don’t want you." (Republic of Ireland university C)

Overall, in contrast with Van den Brink et al. (2013), our findings suggest that the recruitment process across the three contexts was transparent, as illustrated by the use of job descriptions and the open appointment system where recruits were often unknown to the recruiter. In the Republic of Ireland, recruitment into permanent positions often came from those currently in contract positions but the initial recruitment into contract positions was itself transparent. Van den Brink et al. (2013) contrasted such transparency with autonomy but our findings show that the distinction between transparency and autonomy varied with context. In the Scottish universities, both old and new, there was wider school and university pressure to recruit $\mathrm{PhD}$ qualified candidates in order to better meet the universities' strategic objectives, especially in relation to research performance. The heads of department expressed their own clear personal preference for a professionally qualified accountant who has subsequently undertaken a $\mathrm{PhD}$ but they realised that this was no longer likely to materialise. The greatest degree of autonomy was evident in the Republic of Ireland where heads were still able to recruit from professionally qualified applicants. Across the three sectors, the discussions revolved around the qualifications of recruits, signifying that talent was being defined primarily in terms of qualifications rather than other attributes. 


\section{Power of Human Resources versus Power of Academics}

The prior recruitment literature suggested that human resources are becoming more managed, more strategic and having an increased influence on organisations (Novicevic and Harvey, 2001; SHRM, 2006, 2008; CRANET/ SHRM/CIHRS, 2015). In this study, however, no head of department mentioned the involvement of human resources at all in relation to recruitment other than in relation to process, for example in the preparation of a person specification. Academics appeared able to influence recruitment considerably with human resources departments playing only a light-touch administrative role, leaving actual recruitment decisions to academics. The use of the vocabulary of job or person specifications shows the influence of human resources departments on administrative aspects of recruitment and indicated that the recruitment process had become more structured and transparent but no head of department indicated that human resources played any further part in selection.

In line with Metcalfe et al.'s (2005) findings that academics had a significant degree of control over recruitment, and with human resources good practice that human resources should play a supportive role (Martin et al., 2010), we found that recruitment was largely under the control of academics rather than human resource staff in all three of our contexts. However, this did not mean that they were able to act autonomously. The influence did not come from human resources; rather it came from higher levels in the academic hierarchy.

Talent management, the wider university and strategic objectives

Heads of department indicated that there was considerable centralisation (Parker, 2002) which meant that their ability to set their own agenda was limited, once again showing an 
alignment between talent management and strategic objectives. This applied across the three classifications of universities, ranging from Scottish old universities:

We can't do anything that is bizarrely different from the rest of the college, if the rest of the college was just departments we would have a lot more say (Scottish old university A)

to Scottish new universities:

We've had changes at senior management level where they have a very, kind of, centrist and autocratic approach to who gets recruited... I used to have a lot of latitude in shaping things but now, increasingly, that seems to be taken away from me (Scottish new university $\mathrm{H}$ )

and also to universities in the Republic of Ireland:

There's certainly, if you like, a greater formality creeping in to the discretion that people are allowed on their recruitment process (Republic of Ireland university C)

The above quotes show that decision making has been centralised and that departments have to adhere to common financial policies and formalised procedures (Parker, 2011a).

Respondents pointed to the requirement to conform to wider university recruitment policies, for example, setting a master's degree or PhD as an essential requirement, and suggested that their previous flexibility had disappeared. These findings were common across the three university classifications. One head who had responsibility for a wider business school as well as for accounting commented:

Accounting has to tow the line and if I want PhDs in management I also have to require in accounting because of the framework but it's become particularly perhaps sensitive and we cannot say we require a $\mathrm{PhD}$ in management but if you are an accountant you don't. So I have to have a level baseline (Scottish new university F)

\section{Corporatisation}

Prior literature suggested that the growth of business and management schools had been accompanied by corporatisation (Lorange, 2006; Parker, 2011a, 2011b). This was evident in the references to examples of corporate language used across the three contexts. In the three sectors, heads of department referred to 'performance management', 'workload models', 'strategic drivers' and 'quality assurance'. These impacted upon recruitment because it was 
important to recruit someone who would satisfy the measures, for example by publishing at a specified level or contributing to overall research (pointedly not teaching) strategy, within a context where workload models quantified gaps to be filled and favoured researchers.

Consistent with Ashton et al., (2009), these responses indicate that the heads of department did feel a loss of autonomy in various aspects of their management including recruitment but that this was coming from a higher level in the academic hierarchy rather than from human resources. The effect is a reduction in diversity. Instead, we found homogeneity in terms of having policies that apply across the school or university rather than just across an individual department. Hence structural change and the introduction of corporate-style management policies were drivers for change.

Overall, our findings confirm those of Van den Brink et al. (2013) that power continues to reside with academics rather than with human resource professionals but they differ from Van den Brink et al.'s findings in one respect. Although we found that power resided with academics, power did not vest in our heads of department. They felt constrained by wider institutional policy and had to comply with procedures that were set at a higher level in the hierarchy. Across our three contexts, a more corporate-style of management was evident and, as one of our interviewees (Scottish new university F) put it, 'accounting has to tow the line'.

\section{Equality versus Homogeneity}

The human resources literature suggested that academics often appoint in their own image, with tendencies towards homogeneity rather than equality (Essed, 2004), and with potential gender bias (Husu, 2000). Our findings are mixed here. In Scotland, recruitment practices appeared to have been driven primarily by institutional rather than personal preferences. 
Heads came from a range of qualification backgrounds but these did not seem to have affected their comments. For example, one head with a $\mathrm{PhD}$ who did not possess a professional qualification said: 'My ideal candidate: professionally qualified turned academic'. Thus, there did not appear to be a homogenising effect. This contrasts with the Republic of Ireland heads who generally preferred a professionally-qualified recruit who then undertook $\mathrm{PhD}$ studies, the route taken by four of the five heads themselves.

Only one example was cited of a department recruiting a former student, a practice that would exemplify the remnants of the previous collegial culture (Saravanamutha and Tinker, 2002; Christopher, 2012) in which departments recruited people they knew in order to shape the kind of department they wished to be. The fact that this example was cited as being unusual indicates that the emphasis has shifted from autonomy to transparency and from homogeneity to equality. Equality is further indicated by references to the market, in that selection takes place from what the market generates rather than from personal contacts. This market may also play a part in the acceleration of the trend towards $\mathrm{PhD}$ recruits. Several heads commented that they simply do not get many applications any more from professionally qualified candidates:

We were getting more people who had done the $\mathrm{PhD}$ route and applying for jobs here rather than traditional, professionally qualified people... There are more PhDs around. But I think the other factors are relevant as well. I think an academic career as opposed to continuing in practice is now less attractive than it was, or put round the other way, the rewards available for somebody who's doing reasonably well in practice, the disparity is now greater than it used to be (Scottish old university E)

In the Scottish new universities, although the heads had their own preferences, they were open to people with more diverse backgrounds thus indicating that, although the current staff in the new universities were quite homogeneous in their qualifications, they were not averse 
to recruiting those from different backgrounds. One head, who was professionally qualified and who had later undertaken a $\mathrm{PhD}$, commented:

Because everybody in accounting apart from one person is all professionally qualified, therefore I think maybe I would be more open to a $\mathrm{PhD}$ because, as long as I have got a balance within the department, then I think, if I had a suitable candidate that ticked all the boxes and that actually satisfied what I was looking for, I wouldn't have any strong view, one way or the other (Scottish new university I)

In the Republic of Ireland, where the preference was for a professionally-qualified recruit, the lack of diversity was recognised:

We are a fairly standard bunch, all come in with a professional qualification and have either succeeded or are fairly well down to the road to succeeding in a $\mathrm{PhD}$ (Republic of Ireland university E)

Therefore, different patterns were evident across the three sectors. In the Scottish old universities, the preference was for a $\mathrm{PhD}$ candidate, despite the fact that many heads of department themselves came from the alternative professional route. In the newer Scottish universities there was greater openness but in the Republic of Ireland the preference remained for a professional accountant. These preferences can be attributed, at least in part, to the research assessment environment and the influence that this had over university strategy.

\section{Research assessment}

Discussions referred frequently to successive research assessment exercises, particularly in the Scottish old universities where it was clearly regarded as the driver of the direction of a department and, consistent with Humphrey et al.'s (1995) early view that research assessment would increasingly define the meaning of UK academic life, it was viewed as exerting 'a great influence on staff recruitment, staff retention, everything' (Scottish old university A)

All heads in the Scottish old universities commented on the influence of research assessment but some were clear that this was an important, but not necessarily the only, factor: 
I don't think you can blame everything on (research assessment) but it's focused the mind. An awful lot of the performance indicators in the university are counted in terms of research postgraduate numbers and research grant income so they are looking at the metrics and perhaps to provide funds to universities and they're looking for easy metrics (Scottish old university C)

The likelihood of publishing in quality journals was considered to be higher for $\mathrm{PhD}$ recruits:

I think the standard of accounting research is so high nowadays, the top journal articles are such a high standard that I think people would find it very hard to hit those journals if they haven't had thorough research training through a PhD. I don't see how else you could possibly do it (Scottish old university D)

These heads of department were clearly aware of their research assessment context and there was a very clear message coming from senior management that performance in this area was crucial. As such, the heads could not act autonomously and the need to perform well on research had clearly influenced the trend towards the favouring of a PhD applicant (Beattie and Goodacre, 2012).

The new Scottish universities also referred to the influence of research assessment on recruitment with the ones being entered into the research assessment process being 'the ones who have been here a couple of years' (Scottish new university G). However, as in the old universities, this was an important, but not the only, driver:

One of our strategic drivers is to improve our business and management research. Therefore I would expect anyone coming in to accounting to accounting contribute to that (Scottish new university F)

These heads were therefore also subject to influences from senior management and could not act as autonomously as in the past Ashton et al. (2009).

Although the Republic of Ireland does not have its own version of research assessment, all heads of department referred frequently to the UK's research assessment process. 
Nonetheless, there was evidence that there are internal review processes in the Republic of

Ireland that are becoming more formalised and are focusing more on research:

We've learned from your mistakes - at least we think we have...we have a different model and it's basically a peer reviewed process where the department in terms of the university picks a panel of three external experts to review the department's research output...We are more accountable now for the money we receive (Republic of Ireland university D)

Irish heads of department did not think that they would get a research assessment process but they felt that they would get something similar, hopefully better, saying of the UK process:

We're delighted that you went through the research assessment process first, and are beyond the good and the bad, because certainly our own civil service are aware it, they've been fully briefed on the downside. What we think, we're unlikely to get such a crude instrument (Republic of Ireland university D)

However, one head suggested that something more formalised would be welcome, commenting that the UK's processes had 'taken a hammer to crack a nut' but continuing that:

I think a bit of measurement, you know I would welcome a bit of measurement because it would put research on the agenda in a way it isn't on the agenda now, but it would also give recognition to the researchers (Republic of Ireland university A)

The Republic of Ireland heads were therefore subject to similar influences even though a formal research assessment process did not exist. They did, feel, however, that the lack of a formal process gave them more autonomy than their Scottish counterparts. The above quotes show that research assessment requires to be contextualised, that it drives recruitment in the old Scottish universities and that its impact is being felt in the new Scottish universities and in the Republic of Ireland, but in different ways and for different reasons.

Overall, in relation to equality and homogeneity, our findings differ from those of Van den Brink et al., (2013), particularly in Scotland. Whereas they found a high degree of homogeneity, we found, in Scotland in particular, that heads were unlikely to recruit in their own image because of the trend towards $\mathrm{PhD}$ recruitment, driven largely by the demands of research assessment. Heads in the Republic of Ireland were more likely to recruit in their 
own (professional) image but even in that context, without research assessment, there were indications that the recruitment landscape was beginning to change.

\section{$\underline{\text { Discussion and Conclusions }}$}

This paper finds that the three key dilemmas relating to human resource management for universities identified by Van den Brink et al. (2013) provide a useful framework for the examination of recruitment into academia. Following Van den Brink et al. (2013), we are able to situate recruitment in our context in relation to these three dilemmas. However the previous section has shown that our findings differ in several respects from those of Van den Brink et al. (2013). Like Van den Brink et al., we found that academics rather than human resources staff held the power over recruitment, though power now vested in higher levels in the hierarchy rather than being located at the more granular, departmental level. However, while they found a largely autonomous and homogeneous recruitment process, we found greater evidence of transparency and equality. Van den Brink et al. (2013: 181) emphasised that recruitment and selection were 'embedded in a 'global, economic, political and sociocultural context'. Our findings support this view and we now turn to examine these contextual factors in more detail in order to attempt to explain our differing findings. In particular, we focus on the interplay between our subfield of accounting and context.

It was clear that one reason for our different findings was the growing importance of the business or management school, often set within a larger college, as the locus of decisionmaking. Accounting academics had to operationalise school and college policies but they had lost the autonomy which had accompanied the previous primary focus on the nowdefunct accounting department (Lorange, 2006). Departments had been replaced by divisions 
within a business school setting and this had served to retain power in the hands of academics but this power had been taken away from narrow disciplinary specialists as universities had centralised so that power now resided with more senior management.

There remains a question of how much of the shift in recruitment is attributable to the business school model. The influence of senior management was evident in respondents' references to decisions no longer being taken at departmental level but being located within centralised policies applicable across disciplinary areas. This approach aims to ensure consistency and equality across disciplines but fails to recognise differences in supply between disciplines (Hopper, 2013). The business or management school was found to be the prevalent structural model and this appears to have lent impetus to centralisation but the heads' references to 'senior management' as well as to the business school suggest that the higher levels of the university would have driven recruitment changes whether or not a business or management school existed. The business school model appears to have exacerbated the shift in recruitment but it is possible that such a shift might have happened whether the business school or another configuration was used. Whatever the structural impetus, heads of department clearly felt constrained by wider policies that had left them with less autonomy than in the past when they operated as stand-alone departments.

Business schools have been criticised for being too vocational (Wren, Halbesleben and Buckley, 2007) but, at the same time, they are recognised as having an ethos that is different from the rest of the university, straddling both academia and the world of practice, which can create a tension between competing concerns about rigour and relevance (Clinebell and Clinebell, 2008). Hence it is not surprising that they have responded by emphasising their academic credential via academic participation in refereed journals and scientific 
conferences, which had previously been associated with more established university disciplines (Thomas and Wilson, 2011; Alajoutsijärvi et al., 2015). The recruitment of academically-qualified $\mathrm{PhD}$ holders continues this shift. However, such a stance, which we find being operationalised in recruitment in accounting, privileges the $\mathrm{PhD}$ holder over the professionally qualified applicant which threatens to address the lack of academic rigour by shifting to a position that will over time reduce the professional experience of faculty.

Our findings show that the well documented shift in recruitment (Zeff, 1997; Brown et al, 2007; Duff and Monk, 2006) from a professionally qualified to $\mathrm{PhD}$ recruit has become even more entrenched. Talent is therefore being defined very narrowly, primarily in terms of preferred qualifications. In the Scottish old universities, interviewees stated frequently that the benefit of recruiting professionally qualified people was their ability to teach across a wide range of disciplinary areas, bringing their work experience as well as knowledge to bear and having a professional approach to work. However, these heads stated that such a person would be likely to lose out to a PhD-holder who is perceived to be less of a research risk. Whilst not quite so evident among the new Scottish universities, where the professionally qualified recruit was still the preferred choice for some heads of department, there was still evidence from the interviews that research was becoming more important. In this context, it was actually quite easy for heads to envisage the recruitment of a $\mathrm{PhD}$ qualified person since the majority of staff in post held professional qualifications and so there was less perceived need to add to this qualification group. The expressed preference of heads of department in the Republic of Ireland was for a professionally qualified recruit. They felt that they had more scope to achieve this given that most applicants were professionally-qualified. These heads of department attributed their professional preference to the fact that they were not operating within the framework of research assessment. 
Across all sectors, research assessment was clearly at the forefront of all minds, not necessarily exclusively, but certainly in conjunction with research performance generally. The effect was most marked amongst the old Scottish universities where the need to perform well in research assessment led to the recruitment of $\mathrm{PhD}$ holders in order to minimise the risk of non-publishing but it was also evident in the new Scottish universities. In contrast, Irish heads expressed relief that they did not have the UK's system but they were aware of the emerging research pressures, although to a considerably lesser extent than in Scotland.

It was clear that research assessment had influenced the strategic priorities of old and new universities in Scotland (Beattie and Goodacre, 2012) which in turn had led to the focus on appointing recruits able to meet the research priority. This privileges research over the other aspects of an academic role despite the fact, recognised by all heads, that they needed people to contribute across a range of academic activities including teaching, administrative duties and business/professional engagement, all of which contribute to the academic's identity (Feather, 2016). The newer Scottish universities were still able to place some importance on teaching when recruiting but the research priority was ever-increasing. Our findings show that the underlying assumption behind the shift to $\mathrm{PhD}$ recruitment was that talent could be acquired through the $\mathrm{PhD}$ process and that the $\mathrm{PhD}$ was an indicator of potential, representing an output approach. This confirms the growing evidence that the perceived quality and journal rankings of an individual's research is increasingly influencing recruitment and promotion decisions (Beattie and Goodacre, 2012; Brooks, Fenton and Walker, 2014). In the Republic of Ireland, greater latitude was possible because the strategic focus of their universities was more balanced between research and teaching, although the shift towards a research focus was more obvious than in the past. This confirms a trend, also noted in 
Norway, that a heightened focus on research productivity is increasingly evident in countries without formalised research assessment (Kyvik and Aksnen, 2015). Nonetheless, the continuation of some differences across our contexts, despite a degree of homogenisation, shows that different academic identities continue to manifest themselves in relation to the variation in activities that academics are expected to engage in (Boyd and Smith, 2016).

Overall, therefore, we find that the three key dilemmas are evident within the accounting discipline in our selected contexts but that they manifest themselves in different ways from prior literature as a result of the interplay of a range of ways of defining talent and specific contextual factors. Three contextual factors have contributed to our different findings: the emergence of the business school as the main decision-making unit, the influence of research assessment, and the associated trend towards the recruitment of professionally-qualified rather than $\mathrm{PhD}$ recruits. Our analysis has compared the accounting discipline across two different geographical contexts that display different conditions and approaches, with different recruitment outcomes. This paper therefore shows that there are differences in relation to the three dilemmas across disciplines (in our case accounting, when compared with Van den Brink's (2013) focus on the humanities, STEM subjects and medical sciences). Furthermore, specific contextual factors influence recruitment even within the same discipline when different geographical (here, in relation to Scotland and the Republic of Ireland) contexts across different institutional types (here, old and new Scottish universities) are examined. We conclude, therefore, that it is important to consider the interplay between subfield and context in order to better understand the operation of academic recruitment.

\section{$\underline{\text { References }}$}

ACAS. 2014. Recruitment and Induction. London: ACAS. 
Alajoutsijärvi, K., K. Juusola, and M. Siltaoja. 2013. "The legitimacy paradox of business schools: Losing by gaining?" Academy of Management Learning and Education 14: 277291.

Arnold, A.J., and M.J. Sherer. 1988. "A weighting for accountants in Southern universities?" British Accounting Review 20: 267-273.

Ashton, D., V. Beattie, J. Broadbent, C. Brooks, P. Draper, M. Ezzamel, D Gwilliam et al. 2009. "British research in accounting and finance (2001-2007): The 2008 Research Assessment Exercise.” British Accounting Review 41: 199-207.

Beattie, V., and A. Goodacre. 2012. "Publishing records of accounting and finance faculty promoted to professor: evidence from the UK", Accounting and Business Research 42: 197231.

Braun, V. and V. Clarke, V. 2006. "Using thematic analysis in psychology." Qualitative Research in Psychology 3: 77-101.

Brooks, C., E.M. Fenton, and J.T. Walker. 2014. "Gender and the evaluation of research." Research Policy 43: 990-1001.

Bourdieu, P. 1988. Homo Academicus. Cambridge: Polity Press.

Brown, R., M. Jones, and T. Steele. 2007. "Still flickering at the margins of existence? Publishing patterns and themes in accounting and finance research over the last two decades." British Accounting Review 39: 125-151.

Boyd, P. and C. Smith. 2016. "The contemporary academic: orientation towards research work and researcher identity of higher education lecturers in the health professions." Studies in Higher Education 41: 678-695.

Butler, N., and S. Spoelstra. 2014. "The Regime of Excellence and the Erosion of Ethos in Critical Management Studies.” British Journal of Management 25: 538-550.

Christopher, J. 2012. "Tension between the corporate and collegial cultures of Australian public universities: The current status." Critical Perspectives on Accounting 23: 556-571.

Clarke, T. 2008. "The business schools: 50 years on." Education and Training 50: 52-54.

Clarke, V. and V. Braun. 2013. "Teaching thematic analysis: Overcoming challenges and developing strategies for effective learning." The Psychologist 26: 120-123.

Clinebell, S.K., and J.M. Clinebell. 2008. "The tension in business education between academic rigor and real-world relevance: The role of executive professors." Academy of Management Learning and Education 7: 99-107.

CRANET/ SHRM/CIHRS. 2015. Human Resource Management Policies and Practices in the United States. Cranfield Network on International Human Resource Management (CRANET) in collaboration with the Society for Human Resource Management (SHRM) and 
the Center for International HR Studies in the School of Labor Employment Relations at The Pennsylvania State University (CIHRS): Cranfield.

Deem, R. 1998. "New managerialism and higher education: the management of performances and cultures in universities in the United Kingdom." International Studies in Sociology of Education 8: 47-70.

Dries, N. 2013. "The psychology of talent management: A review and research agenda." Human Resource Management Review 23: 272-285.

Duff, A., and E. Monk. 2006. "Attitudes of new appointees to accounting and finance departments in the higher education sector." British Accounting Review 38: 193-220.

Essed, P. 2004. "Cloning among professors: normativities and imagined homogeneities." Nordic Journal of Feminist and Gender Research 12: 113-122.

Farndale, E., H. Scullion, and P. Sparrow. 2010. "The role of the corporate HR function in global talent management.” Journal of World Business 45: 161-168.

Feather, D. 2016. "Defining academic - real or imagined." Studies in Higher Education 41: 110-123.

Guest, G., A. Bunce, A., and L. Johnson. 2006. "How many interviews are enough? An experimentation with data saturation and variability." Field Methods 18: 59-82.

Harley, S., and F.S. Lee. 1997. "Research selectivity, managerialism, and the academic labor process: The future of nonmainstream Economics in UK universities." Human Relations 50: $1427-1460$.

Hinings, C.R., R. Thibault, T. Slack, and L.M. Kikulis. 1996. "Values and Organizational Structure." Human Relations 49: 885-916

Holland, K. 1991. "Recruitment by accounting departments in the higher education sector: an analysis of recent employees." British Accounting Review 23: 49-66.

Hopper, T. 2013. "Making accounting degrees fit for a university." Critical Perspectives on Accounting 24: 127-135.

Humphrey, C., P. Moizer, and D. Owen. 1995. "Questioning the value of the research selectivity process in British university accounting." Accounting, Auditing and Accountability Journal 8: 141-164.

Husu, L. 2000. "Gender discrimination in the promised land of gender equality." Higher Education in Europe 25: 221-228.

Kyvik, S., and D.W. Aksnes. 2015. "Explaining the increase in publication productivity among academic staff: A generational perspective." Studies in Higher Education 40:14381453. 
Lawrence, S., and U. Sharma. 2002. "Commodification of education and academic labour using the balanced scorecard in a university setting." Critical Perspectives on Accounting 13: 661-677.

Lorange, P. 2006. "A performance based, minimalist human resources management approach in business schools." Human Resource Management 45: 649-658.

Macdonald, S., and J. Kam. 2011. "The skewed few: people and papers of quality in management studies." Organization 18: 467-475.

Macve, R. 1989. "The crisis in the classroom: a profession at risk." The Accountant Sept., 810 .

Martin, M., F. Whiting, and T. Jackson. 2010. Human Resource Practice. London: Chartered Institute of Personnel and Development.

McKenna, S., J. Richardson, J., and L. Manroop. 2010. "Alternative paradigms and the study and practice of performance management and evaluation." Human Resource Management Review 21: 148-157.

Metcalfe, H., H. Rolfe, P. Stevens, and M. Weale. 2005. Recruitment and retention of academic staff in higher education. Nottingham: National Institute of Economic and Social Research.

Meyers, M.C., M. van Woerkom, and N. Dries. 2013. "Talent — Innate or acquired? Theoretical considerations and their implications for talent management." Human Resource Management Review 23: 305-321.

Minbaeva, D., and D.G. Collings. 2013. "Seven myths of global talent management." International Journal of Human Resource Management 24: 1762-1776.

Mingers, J., and H. Willmott, H. 2013. "Taylorizing business school research: On the 'one best way’ performative effects of journal ranking lists.” Human Relations 66: 1051-1073.

Novicevic, M.M., and Harvey, M. 2001. "The changing role of the corporate HR function in global organizations of the twenty-first century." International Journal of Human Resource Management 12: 1251-1268.

Otley, D. 2002. "British research in accounting and finance (1996-2000): The 2001 Research Assessment Exercise." British Accounting Review 34: 387-417.

Parker, L. 2002. "It's been a pleasure doing business with you: A strategic analysis and critique of university change management." Critical Perspectives on Accounting 13: 603-619.

Parker, L. 2011a. "University corporatization: Driving definition." Critical Perspectives on Accounting 22: 434-450.

Parker, L.D. 2011b. "Contemporary university strategizing: The financial imperative". Financial Accountability and Management 29: 1-25. 
Rowlinson N., and J. Hassard. 2011. "How come the critters came to be teaching in business schools? Contradictions in the institutionalization of critical management studies." Organization 18: 673-689.

Rowlinson, M., C. Harvey, A. Kelly, H. Morris, and E. Todeva. 2015. "Accounting for research quality: Research audits and the journal rankings debate." Critical Perspectives on Accounting 26: 2-22.

Saravanamutha, K., and T. Tinker. 2002. "The university in the new corporate world." Critical Perspectives on Accounting 13: 545-554.

Scullion, H., and D.G. Collings. 2011. Global Talent Management. Routledge: London and New York.

Scullion, H., D.G. Collings, and P. Caligiuri. 2010. "Global Talent Management." Journal of World Business 45(2): 105-108.

SHRM. (2006). Finding and Keeping the Right Talent - A Strategic View. Society for Human Resource Management: Alexandria, VA.

SHRM. (2008). HR's Evolving Role in Organizations and its Impact on Business Strategy Linking Critical HR Functions to Organizational Success. Society for Human Resource Management: Alexandria, VA.

Sparrow, P., E. Farndale, and H. Scullion. 2013. "An empirical study of the role of the corporate HR function in global talent management in professional and financial service firms in the global financial crisis." International Journal of Human Resource Management 24: $1777-1798$.

Stahl, G.K., I. Björkman, E. Farndale, S.S. Morris, J. Paauwe, P. Stiles, J. Trevor, and P.M. Wright. 2012. "Six principles of effective global talent management." MIT Sloan Management Review 53: 24-32.

Tansley, C., and S. Tietze. 2013. "Rites of passage through talent management progression stages: an identity work perspective." International Journal of Human Resource Management 24: 1799-1815.

Thomas, H., and A.D. Wilson. 2011. “'Physics envy,' cognitive legitimacy or practical relevance: Dilemmas in the evolution of management research in the UK." British Journal of Management 22: 443-456.

Thunnissen, M., P. Boselie,, and B. Fruytier. 2013a. "A review of talent management: infancy or adolescence?", International Journal of Human Resource Management 24: 17441761.

Thunnissen, M., P. Boselie, P. and B. Fruytier. 2013b. "Talent management and the relevance of context: Towards a pluralistic approach." Human Resource Management Review 23: 326336. 
Tourish, D. 2011. "Leading questions: Journal rankings, academic freedom and performativity: What is, or should be, the future of leadership?" Leadership 7: 367-381.

Universities UK. 2007. Talent Wars: The international market for academic staff. Universities UK: London.

Van den Brink, M., M. Thunnissen, and B. Fruytier. 2013. "Talent management in academia: performance systems and HRM policies.” Human Resource Management Journal 23: 180195.

Watson, T.J. 2004. "HRM and critical social science analysis." Journal of Management Studies 41: 447-467.

Weetman, P. 1993. "Recruitment by accounting departments in the higher education sector: a comment on the Scottish experience". British Accounting Review 25: 287-300.

Williams, A.P.O. 2010. The history of UK business and management education. Bingley: Emerald

Willmott, H. 1995. "Managing the academics: Commodification and control in the development of university education in the UK." Human Relations 48: 993-1027.

Willmott, H. 2011. "Journal list fetishism and the perversion of scholarship: reactivity and the ABS list." Organization 18: 429-442.

Wren, D.A., J.R.B. Halbesleben., and M.R. Buckley. 2007. "The theory-application balance in management pedagogy: A longitudinal update. " Academy of Management Learning and Education, 6: 484-492.

Zeff, S.A. 1997. "The early years of the Association of University Teachers of Accounting: 1947-1959.” British Accounting Review Special Issue (June): 3-39.

\footnotetext{
${ }^{\mathrm{i}}$ The Universities of St. Andrews, Glasgow, Aberdeen and Edinburgh.

ii The Universities of Dundee, Heriot-Watt, Stirling and Strathclyde.

iii The Universities of Abertay, Glasgow Caledonian, Napier, Robert Gordon, West of Scotland and, most recently, the University of the Highlands and Islands.

${ }^{\text {iv }}$ Trinity College Dublin, University College Cork, University College Dublin, National University of Ireland Galway, Dublin City University, National University of Ireland Maynooth and the University of Limerick.

${ }^{v}$ Departments had a variety of names. Interviews were held with the head of a department that included Accounting in its name.

${ }^{\text {vi }}$ The longest transcript was 15,838 words, the shortest 5,361 words, with a median length of 8,975 words and an average length of 10,008 words.

${ }^{\text {vii }}$ No further details are given as this could identify the interviewees.

${ }^{\text {viii }}$ The following codes were initially used: context, mission, ideal recruit, characteristics of recruits, qualifications, $\mathrm{PhD}$, professionally qualified, job market, recent recruitment experiences, supply and demand, process, driver, job specification, research assessment, head of department, school, university, human resources.
} 